5. Артемьева Е.А., Муравьев И.В. К истории изучения изменчивости окраски оперения «желтых» трясогузок (Passeriformes, Motacillidae, Motacillinae): от Н.А. Зарудного до наших дней // Материалы международной конференции «Наземные позвоночные животные аридных экосистем», посвященной памяти Н.А Зарудного (24-27 октября; 2012; Ташкент). Ташкент: Chinor ENK, 2012г. C. 24-34.

6. Vili N., Chavko J., Szabó K., Kovács S., Hornung E., Kalmár L., Horváth M. 2009: Genetic structure of the Imperial Eagle (Aquila heliaca) population in Slovakia. Slovak Rapt J. 2009. №3. P. 21-28.

7. Редькин Я.А. Таксономические отношения форм в эволюционно молодых комплексах птиц на примере рода Motacilla L., 1785 (таксономическая ревизия подрода Budytes): Автореф. дис. ... канд. биол. наук. М.: МГПИ, 2001. 19 с.

8. Артемьева Е.А., Муравьев И.В. Симпатрия «желтых» трясогузок (Passeriformes, Motacillidae, Motacillinae): география, экология, эволюция. Части 1, 2. М.: Флинта-Наука, 2012б. 152 с., 200 с.

9. Artemieva E.A., Muraviev I.V., Beme I.R. Yellow Wagtail Motacilla flava Linnaeus, 1758 (Passeriformes, Motacillidae, Motacillinae), in the Middle Volga Region: Geographical Distribution, Nesting Biotopes, and Numbers // Moscow Univ. Biol. Sci. Bull. 2013. Vol. 68. №3. P. $131-142$.

GENETIC BASE FOR SYMPATRY OF YELLOW WAGTAIL MOTACILLA FLAVA LINNAEUS, 1758 AND YELLOW-HEADED WAGTAIL MOTACILLA CITREOLA PALLAS, (C) 2015 1776 (MOTACILLIDAE, PASSERIFORMES) IN THE MIDDLE VOLGA REGION

E.A. Artemyeva, doctor of Biological Sciences, Associate Professor, Professor at the Department of Zoology

I.N. Ulyanov Ulyanovsk State Pedagogical University, Ulyanovsk (Russia)

A.V. Mishchenko, Candidate of Biological Sciences, Associate Professor, Associate Professor at the Department of Zoology

I.N. Ulyanov Ulyanovsk State Pedagogical University, Ulyanovsk (Russia)

D.K. Makarov, post-graduate student of department of Zoology

I.N. Ulyanov Ulyanovsk State Pedagogical University, Ulyanovsk (Russia)

Annotation. We investigated the genetic basis between sympatric breeding population yellow wagtail Motacilla flava and yellow-headed wagtail Motacilla citreola in the Middle Volga region. We lead the phylogeographic analysis of the nucleotide sequences in the mitochondrial gene of oxidase I cytochromes in yellow wagtail Motacilla flava and yellowheaded wagtail M. citreola populations of Middle Volga. As part of the traditionally recognized species M. flava and M. citreola revealed the existence of separate lines, common in the European part of Russia and neighboring countries and associated with the presence of Middle Volga populations of subspecies of M. f. flava, M. f. thunbergi and M. c. citreola, M. c. werae respectively. The forms of M. c. citreola and M. c. werae due to significant genetic distances deserve assigning them the status of the species. These results suggest that, despite the broad sympatry in nesting places, there is a selective mating between males and females of each species studied, which prevents from the free crossing and supports the insulating mechanisms in populations.

Keywords: phenotype; genotype; sympatry; population; mitochondrial DNA; wagtails; Middle Volga region.

УДК 595.4

(C) 2015 ХИЩНИКИ И ПАРАЗИТЫ ПАУКОВ (ARANEI) САМАРСКОЙ ОБЛАСТИ

Е.А.Белослудцев, заведующий отделом позвоночных животных зоологического музея им. Д.Н.Флорова

Поволжская государственная сочиально-гуманитарная академия, Самара, (Россия)

Аннотаџия. Пауки-хищники и нередко массовые выполняют важную роль в регуляции численности насекомых и других беспозвоночных животных. Однако значение пауков как истребителей членистоногих несколько снижается из-за большого количества имеющихся у них естественных врагов. На пауков ведут охоту ради пропитания животные из классов Reptilia и Amphibia. Выкармливают своих птенцов пауками птицы (Aves). Использует в пищу пауков Mantispa styriaca L. (Neuroptera). Ловят и относят в муравейник пауков муравьи из родов Fоrmica и Myrmica. На теле пауков паразитируют некоторые виды из отряда Diptera и подкласса Acarina. Для выкармливания своих личинок запасают в своих ячейках пауков роющие осы (Sphecidae). Самыми опасными и многочисленными врагами пауков являются дорожные осы из семейства Pompilidae отряда перепончатокрылых (Hymenoptera). Пауки могут представлять угрозу и для других пауков, то есть использовать в пищу не только другие виды пауков, но и молодых особей своего вида. В нашей работе приводятся данные о 39 видов пауков, обитающих в Самарской области, для которых обнаружено более 48 видов хищников и паразитов.

Ключевые слова: пауки; хищники; паразиты.

Пауки-хищники и нередко массовые выполняют важную роль в регуляции численности насекомых и других беспозвоночных [1]. Однако значение пауков как истребителей членистоногих несколько снижается из-за большого количества имеющихся у них естественных врагов. Поэтому мы решили выяснить, кто охотится на пауков или паразитирует на них в условиях Самарской области.

Пауки служат пищей птицам и используются ими для выкармливания птенцов, так как являются мягким и легко перевариваемым кормом [2]. Например, паук крестовик, обычный объект питания корольков, гаечек и хохлатых синиц, а Larinioides cornutus $\mathrm{Cl}$--овсянкикрошки и пеночки веснички [3]. А вот доля пауков в пище птенцов лазоревки достигает до 50\% [4]. На пауков охотятся и ящерицы, до 8,6\% от объема пищи было найдено араней в желудке прыткой ящерицы. Обыкновенная жаба предпочитает пауков рода Pardosa и других крупных Lycosidae [1].

Одним из активных хищников пауков Самарской области является мантиспа-Mantispa styriaca L. (Neuroptera). Личинка ее выходит из красного яйца, проводит без пищи зиму, а весной выискивает самку паука из семейства Lycosidae, забирается в кокон, 
Е.А. Белослудцев ХИЩНИКИ И ПАРАЗИТЫ ПАУКОВ (АRАNЕI) САМАРСКОЙ ОБЛАСТИ ...

который самка носит всегда с собой, линяет, несколько изменяя свою форму, после чего начинает питаться паучьими яйцами. Там же личинка и окукливается, а перед превращением в имаго оставляет кокон и заползает в трещины почв [5].

Врагами пауков (особенно Lycosidae) являются три вида муравьев [6] (табл. 1). Достаточно высокая подвижность паукообразных делает их менее уязвимыми для муравьев, а их низкая плотность не стимулирует муравьев к активной охоте на них. Пауки, входя в состав пищевого рациона муравьев, основу его не составляют, поэтому трофическая связь в системе хищник-жертва, в которой муравьи выступают как хищники, а паукообразные-жертвы, очень слабая. Хотя в экстремальных условиях муравьи вынуждены (для поддержания оптимального размера семьи) доставлять в гнездо высококалорийную пищу, которой являются для них такие живые объекты, как пауки [7].

Эктопаразитами арахнид являются некоторые виды отряда Diptera [8]. Они заражают яйцекладки пауков. Внутри коконов обнаруживается обычно по одной довольно крупной личинке, а яйца паука заметно оттеснены к периферии, сильно спрессованы, не прозрачны и не жизнеспособны. Хищные личинки, поражающие коконы пауков относятся к видам двух семейств и 4 родов (табл. 1). Они паразитируют на пауках из 3 семейств и 5 родов, обитающих в нашей области.

На теле пауков могут паразитировать клещи из семейств Gamasidae, Ixodidae, Trombiculidae [7].

Запасают пауков в ячейках гнезд для выкармливания своих личинок роющие осы (Sphecidae) из отряда перепончакрылых (Hymenoptera). Но самыми опасными и многочисленными врагами пауков являются дорожные осы из семейства Pompilidae $[9,10,11,12]$. У пауков все нервные узлы, управляющие движением ног и брюшка, слиты в один грудной узел. Именно сюда и направляет свое жало дорожная оса, чтобы обездвижить добычу. Но прежде, чем сделать это, оса обычно погружает жало в рот паука и обезвреживает его ядовитый аппарат. Уколом жала в нервные центры оса парализует паука, не убивая его, а затем перетаскивает в свою норку $[13,14,15]$. На тело добычи откладывается яйцо, выходящая личинка питается пауками как «живыми консервами». Например, основным объектом охоты дорожной осы Anoplius viaticus L. являются пауки Trochosa ruricola De Geer. и T. terricola Thor. (сем. Lycosidae). Переход на питание другими видами пауков происходит редко [16]. По литературным данным, в Самарской области обитает 22 вида ос и 19 видов наездников, для которых удалось установить семейства, рода и виды пауков жертв (табл. 1) Для большинства других видов перепончатокрылых, приведенных в таблице 1, было указано, что эти представители паразитируют на пауках или охотятся на них $[17,13]$.

В пределах отряда Aranei встречаются пауки, которые питаются особями других видов пауков. Это арахниды из семейства Mimetidae-они подкарауливают, повисая над почвой, и хватают шипастыми передними ногами свою жертву [18]. Пауки бокоходы, питающиеся двукрылыми, тоже могут охотиться за пауками. До 10\% их добычи составляют пауки, в основном из семейства Lycosidae [19]. Пауки могут иметь и псевдоканнибалистические отношения. Под этим понимается пожирание пауков пауками (хищников хищниками в пределах одного трофического уровня) [20].

Таким образом, по литературным данным, для 39 видов пауков из 37 родов и 16 семейств, обитающих в Самарской области, выявлено паразитов и хищников более 48 видов из 8 отрядов и 5 классов, представленных позвоночными и беспозвоночными животными (табл.1). Для остальных видов Aranei Самарской области сведения о паразитах и хищниках практически отсутствуют.

Самарский научный вестник. 2015. № 2(11)
Хищиники и паразить пауков

\begin{tabular}{|c|c|}
\hline Bemex neysos & 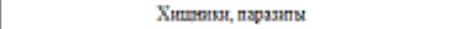 \\
\hline Ces tycesibse & 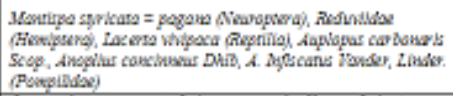 \\
\hline Allahogra angorswats $(\mathrm{Cl}, 1757)$ & 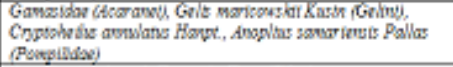 \\
\hline 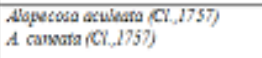 & 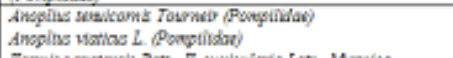 \\
\hline A carsar (Hanse, 183j) & 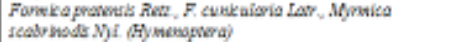 \\
\hline 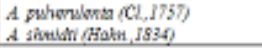 & 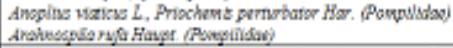 \\
\hline Alopecosa ap & 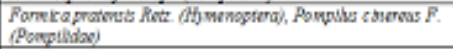 \\
\hline drases sp & 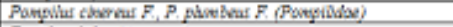 \\
\hline 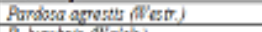 & Iromblculh be (Acaravap) \\
\hline P. higabris (IIGice) & Gole sp Golint) \\
\hline 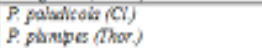 & 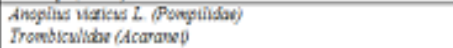 \\
\hline P. phanioga /. Kotá j & 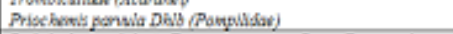 \\
\hline Purdesa sp. & 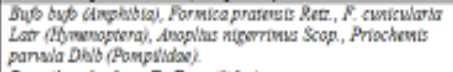 \\
\hline Prafosp & 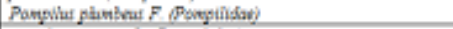 \\
\hline Irachosararscia (De GNer) & 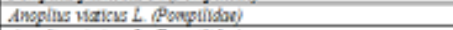 \\
\hline 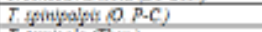 & 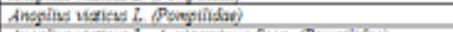 \\
\hline T nerkedia (Thor) & 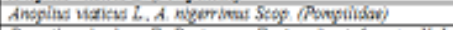 \\
\hline Thochosasp. & 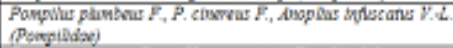 \\
\hline Xenaiusata wimstra C. $L$ Kackj & 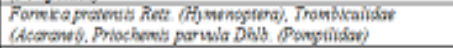 \\
\hline 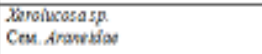 & 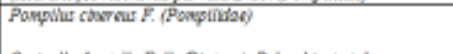 \\
\hline 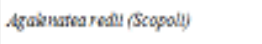 & 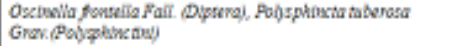 \\
\hline Araness diatirnats (C) & 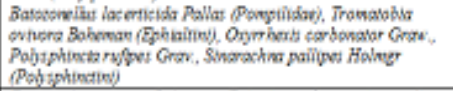 \\
\hline A guastrass (CL) & 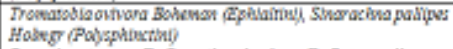 \\
\hline dranos ip & 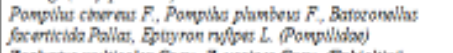 \\
\hline dranbllla curasbinua (C2) & 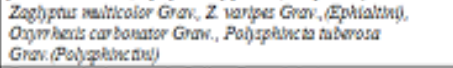 \\
\hline dreigose & 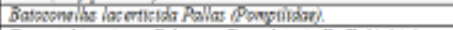 \\
\hline Oriesa centea (Pañes) & 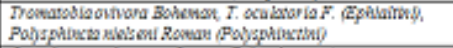 \\
\hline 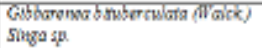 & 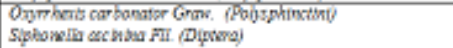 \\
\hline Lartriastes carmane (C) & 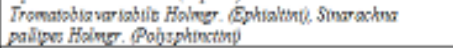 \\
\hline \multicolumn{2}{|l|}{ Cen. Toroguariabe } \\
\hline 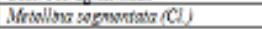 & 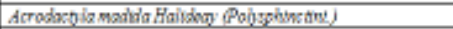 \\
\hline ANallby ys. & 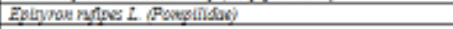 \\
\hline 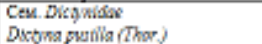 & 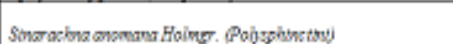 \\
\hline
\end{tabular}

\section{СПИСОК ЛИТЕРАТУРЫ}

1. Савельева Л.Г. Враги пауков (Aranei) из Восточного Казахстана // Фауна и экология паукообразных. Пермь: Пермский ун-т, 1984. С. 78-81.

2. Пауки (Aranei) // Лес России: Энциклопедия / Под общ. ред. А.И. Уткина и др.-М.: Большая рос. энцикл., 1995. С. 297-298.

3. Головатин М.Г., Ольшванг В.Н., Алексеева Н.С. Трофические связи некоторых воробьиных птиц в лесных экосистемах субарктики // Экология. 1991. №2. C. 70-77.

4. Пономарёв А.В., Лебедева Н.В. Пауки (Aranei) и некоторые их ценотические связи в байрачных лесах Нижнего Дона // Аридные экосистемы. Москва: Товарищество научных изданий КМК, 2014. Т. 20. №2 (59). 74-86.

5. Станек В.Я. Иллюстрированная энциклопедия насекомых / Пер. И. Мезловой; Под ред. Е.Г. Бацылева, А.Н. Мешковой-Прага: Артия, 1977. 557 с.

6. Гридина Т.И. Пространственное взаимодействие муравьев рода Formica с паукообразными в разных ландшавтных условиях // Фауна и экология пауков, скорпионов и ложноскорпионов СССР. Тр. Зоол. ин-та AH CCCP, 1990. T. 226. С. 29-37.

7. Лобанова Т.В., Рябикова Т.П. О паразитах и хищниках пауков семейства Lycosidae // Животный мир Сибири и его охрана. Новосибирск: Новосибирск. пед. ин-т, 1980. С. 19-28.

8. Нарчук Э.П. Двукрылые насекомые (Diptera)паразиты пауков (Aranei) // Фауна и экология пауков, скорпионов и ложноскорпионов СССР. Тр. Зоол. Ин-та 
АН СССР. Т. 226. Л.: ЗИН РАН, 1990. С. 19-28.

9. Определитель насекомых Дальнего Востока России. Т. 3. Сетчатокрылые, скорпионницы, перепончатокрылые. Ч.1.-СПб.: Наука, 1995. 606 с.

10. Определитель насекомых европейской части СССР. Т. 3. Перепончатокрылые. Первая часть (В серии: Определители по фауне, издаваемые Зоологическим институтом АН СССР). Вып. 119. Л.: Наука, 1978. 584 с.

11. Определитель насекомых европейской части СССР. T. 3. Перепончатокрылые. Вторая часть. / Ред. В.Н. Алексеев, К.А. Джанокмен, М.Д. Зерева и др. Л. Наука, 1978. 757 с.

12. Определитель насекомых европейской части СССР. Т. 3. Перепончатокрылые. Третья часть / Ред. А.3. Атоманов, В.П. Ионайтис, Д.Р. Каспарян, В.С Куслицкий, А.П. Расницкий, У.В. Сийтан, В.И. Толканец (В серии: Определители по фауне, издаваемые Зоологическим институтом АН СССР) Вып. 129. Л.: Наука $1981.688 \mathrm{c}$

13. Ильина Н.С., Крикунова О.А., Магдеев Д.В., Митрошенкова А.Е., Павлов С.И., Ясюк В.П. Новосемейкино (природа и история): Учебное пособие. Самара: Изд. «ЧП Тарасов», 1994. 120 с.

14. Козлов М.А. Основные типы специализации наездников (Hymenoptera, Parasitica) к хозяивам //

Хозяино-паразитические отношения у насекомых. Л.: Наука, 1972. С. 5-17.

15. Козлов М.А. Отряд Перепончатокрылые (Hymenoptera) // Насекомые. Серия «Животный мир Молдавии». Кишинев: Штиинци, 1983. 376 с.

16. Шляхтенок А.С. Пауки-жертвы дорожной осы Anoplius viaticus L. (Hymenoptera, Pompilidae) // Фауна и экология паукаобразных. Пермь: Пермск. УН-т, 1988. C. $105-109$.

17. Мариковский П.И. В пустынях казахстана. М.: Мысль, 1978. 127 с.

18. Харитонов Д.Е. Пауки-Araneina // Животный мир СССР. М.-Л.: изд-во АН СССР, 1953. Т. 4: Лесная зона. С. 356-365.

19. Хотько Э.И., Ветрова С.Н., Матвеенко А.А., Чумаков Л.С. Почвенные беспозвоночные и промышленные загрезнения. Мн.: Наука и техника, 1982. C. $110-117$.

20. Берман Д.И. О регуляторном значении избытка хищников в стабилизации численности животных в биоценозах // Журнал общей биологии, 1970. Т. XXXI. Вып. 4. С. 436-447.

(C) 2015

\title{
PREDATORS AND PARASITES OF SPIDERS (ARANEI) OF THE SAMARA REGION
}

\author{
E. A. Belosludtsev, head of Invertebrates Department, D.N.Florov Zoology Museum
} Samara State Academy of Social Sciences and Humanities, Samara (Russia)

Annotation. Spiders are the predators and often play an important role in the regulation of insect and other invertebrate animals. However, the importance of spiders as fighters arthropods is somewhat reduced due to the large number of existing natural enemies. The spiders lead the hunt for food animals of the classes Reptilia and Amphibia. The birds (Aves) feed their chicks with spiders. Mantispa styriaca L. (Neuroptera) uses in food of spiders. The ants of the genera Formica and Myrmica catch and carry spiders to the nest. Some species from the order Diptera and the subclass Acarina parasitize on the spiders' body. The wasps (Sphecidae) stock spiders in cells for rearing their larvas. The most dangerous and numerous enemies of spiders are road wasps of the family Pompilidae, the order Hymenoptera. Spiders can pose a threat to other spiders, which are used to eat not only other spiders species of, but the juveniles of their own species. Our work provides data on 39 species of spiders living in the Samara region, with more than 48 species of predators and parasites.

Keywords: spiders; predators; parasites.

\section{УДК 581.9(470.6) ФИТОРАЗНООБРАЗИЕ УРОЧИЩА «СЕМИСТОЖКИ» (ЦЕНТРАЛЬНОЕ ПРЕДКАВКАЗЬЕ)}

(C) 2015

В.Н. Белоус, кандидат биологических наук, доцент, доцент кафедры ботаники, зоологии и общей биологии

Северо-Кавказский федеральный университет, Институт живых систем, Ставрополь (Россия)

Аннотация. В статье отражены результаты исследования флористического и фитоценотического состояния коренных травяных сообществ урочища «Семистожки» (Ставропольская возвышенность). На исследованной территории зарегистрировано не менее 210 видов сосудистых растений, среди которых 11 подлежат региональной охране (субэндемики, ксеротермические реликты, уязвимые и усиленно эксплуатируемые виды). Изученный степной комплекс урочища «Семистожки» отличается заметным разнообразием осваиваемых местообитаний. Определённый фон в распределение флоры и растительности изучаемого ландшафта создают различающиеся характеристики местных почв и климатов. Контрастность проявления местных условий связана с экспозицией и крутизной склонов, составом почвогрунтов, и находит отражение на режиме тепло- и влагообеспеченности эдафотопов урочища. На склонах холмов сохранились целинные богаторазнотравно-дерновиннозлаковые и луговые полидоминантные степные сообщества замечательные своей первозданностью, незатронутые хоть какойлибо хозяйственной деятельностью. Травостой сложно устроенный, ярусно-дифференцированный. Изменение видового состава подъярусов травостоя происходит в течение всего вегетационного сезона. Основу травостоя составляют ксерофиты и мезоксерофиты. Область наиболее ксерофитной растительности расширяется на южных, восточных и промежуточных к ним склонах. Ценозообразователями сообществ южных склонов выступают плотнокустовые дерновинные злаки и разнотравье. На продуктах разрушения материнской породы (песчаник, известняк) и краевых участках плато развиты незамкнутые сериальные сообщества из группы псаммо-петрофитов.

Ключевые слова: репрезентативные травяные сообщества; фиторазнообразие; степная экосистема; Ставропольская возвышенность; Северный Кавказ.

Памятник природы урочище «Семистожки»-часть местности Сычёвско-Воровсколесского останцового массива Ставропольской возвышенности, который наряду с магматическими купольными горными поднятиями Пятигорья представляет Минераловодскую наклонную равнину в предгорьях Большого Кавказа. 